\title{
Alternative production of craft lager beers using artichoke (Cynara scolymus L.) as a hops substitute
}

\author{
Guilherme Lorencini SCHUINA ${ }^{1 *}$ (D), João Olavo Figueiredo QUELHAS ${ }^{1}$, Maurício Bonatto Machado de CASTILHOS², \\ Giovani Brandão Mafra de CARVALHO ${ }^{3}$, Vanildo Luiz DEL BIANCHI ${ }^{4}$
}

\begin{abstract}
Beer is a fermented beverage made from barley malt and hops under the action of a suitable yeast. The main function of hops in the brewing process is to provide bitterness, characteristic flavours and aromas to the beverage. However, hops only began to be added to the formulation of this beverage starting in the ninth century. Therefore, the use of other bitter plants as a substitute for hops may be a viable alternative. This study aimed at evaluating the use of artichoke as a total substitute for hops in American lager craft beer production. The substitution of hops with up to $2 \mathrm{~g} \cdot \mathrm{L}^{-1}$ artichoke resulted in a beer with a quality similar to that of the American lager beer traditionally found in the market. So, artichoke was confirmed to be a viable alternative for hops, having satisfactory physicochemical characteristics and good sensorial acceptance.
\end{abstract}

Keywords: bitterness; brewing; bitter plants.

Practical Application: Apply of a new raw material to replace the hops in the brewing process.

\section{Introduction}

Beer is commonly defined as a fermented beverage produced from barley malt and hops under the action of a suitable yeast (Sanna \& Pretti, 2015). However, beer may also contain adjuncts and substitutes (Sleiman et al., 2010) to malt, such as spices and other ingredients used to confer specific sensory characteristics to the beverage.

Upon analysing the historical evolution of the beer production process, hops were not always used as a raw material, but rather a mixture of herbs and spices called gruit (Morado, 2009). Hops only began to be added to the formulation of this beverage starting in the ninth century; its inclusion, aside from its remarkably bitter taste, might be due to its intrinsic properties that promoted significant preservation of the drink (Barry et al., 2018; Silva \& Faria, 2008). The main function of hops in the brewing process is to provide bitterness, characteristic flavours, and aromas to the beverage (Leonardi et al., 2013). Therefore, the use of other bitter plants as a substitute for hops may be a viable alternative for producing a differentiated and regional product.

Few studies have been conducted on substituting hops with adjuncts. One study (Aniche \& Uwakwe, 1990) evaluated the potential use of Garcinia kola (a typical African fruit) as a substitute for hops in lager beers and obtained well-accepted beers with physicochemical characteristics similar to those of standard beer. Another study (Adenuga et al., 2010) evaluated the use of extracts from Gongronema latifolium, Vernonia amygdalina and Garcinia kola as potential substitutes for hops in sorghum beers, and found sensory acceptance similar to or greater than that found for standard beer.

Due to its geographic location, Brazil has a favourable climate for the growth of several plant species, already used in food, cosmetics, medicines, and folk medicine. The so-called bitter plants are part of this biodiversity and are usually consumed in the form of aqueous infusions, typically in the context of folk medicine. Among these plants, some popular ones include lemon balm, "pau-amargo" and artichoke (Cynara scolymus L.).

Artichoke is a plant from the Asteraceae family, originating from the Middle East and brought to Brazil by European immigrants (Costa et al., 2009). The plant has an eatable part (the bulbs), typically used in gastronomy, and non-eatable part, customarily used with medicinal purposes, such as water infusion (tea) in folk medicine or capsules and other medicinal products (Schütz et al., 2004). Studies have reported that artichoke extracts have hepatoprotective, hypolipidemic and antioxidant activities (Ernst, 1995; Fintelmann, 1996; Kraft, 1997) as a result of the presence of chemical components found in leaves, such as phenolic acids, flavonoids and sesquiterpenes (Noldin et al., 2003).

Therefore, this study aimed to evaluate the use of different concentrations of artichoke as a total substitute for hops in American lager craft beer production, comparing the results with a commercial beer and a standard beer made with hop.

${ }^{3}$ Departamento de Tecnologia, Universidade Estadual de Feira de Santana - UEFS, Feira de Santana, BA, Brasil

${ }^{4}$ Departamento de Engenharia e Tecnologia de Alimentos, Universidade Estadual Paulista - UNESP, São José do Rio Preto, SP, Brasil

*Corresponding author: glschuina@hotmail.com 


\section{Materials and methods}

Pilsen Malt (Agrária ${ }^{\circledR}$, Brazil), Saaz hops (Barth-Hass Group $^{\circledR}$, Germany), Saflager S-23 yeast (Fermentis ${ }^{\circledR}$, France) and artichoke (dried vegetable parts - leaf, flower, and stalk) were purchased locally and sent to the Bioprocess laboratory of the Department of Food Engineering and Technology, Institute of Biosciences, Letters, and Exact Sciences of the São Paulo State University, São José do Rio Preto Campus, for analysis.

\subsection{Brewery production}

Ground malt and water were put in a mashing pan at a ratio of 1:4 (w/w). Mashing was performed through multiple infusion processes, and iodine test was used to verify starch saccharification. At the end of mashing, the wort was filtered in the lauter tun, in which malt husk acted as a filtering layer. After filtration, water was added over the filtering layer at the same temperature of the system to increase the efficiency of sugar extraction. The resulting sweet wort was added to the boil kettle, brought to a boil, and then the hops (standard beer) or the artichoke (test beer) were added. After 60 minutes, the wort was rapidly cooled near inoculation temperature and subjected to circular stirring to promote trub precipitation. At the end of this process, the sedimented material was removed, and the inoculated wort was fermented.

The fermentation lasted for seven days and was carried out at $12{ }^{\circ} \mathrm{C}$ in closed plastic vats $(10 \mathrm{~L})$ equipped with a hydraulic stopper. Subsequently, the excess yeast accumulated at the bottom of the tun was removed, and the maturation stage took place, lasting for 15 days at $0{ }^{\circ} \mathrm{C}$. At the end of this stage, the beers were bottled in glass bottles, in which a $6 \mathrm{~g} \cdot \mathrm{L}^{-1}$ sugar solution was added and kept for seven days at $20^{\circ} \mathrm{C}$ to promote carbonation of the product. After this period, the planned analyses for this study were conducted.

\subsection{Physicochemical analysis}

The following physicochemical parameters were examined in this study: original extract, apparent extract, alcohol content, $\mathrm{pH}$, colour, bitterness, turbidity, and apparent attenuation. All these analyses were performed according to the European Brewery Convention (2010) methodology.

\subsection{Sensory analysis}

The sensory analysis panel consisted of 100 untrained evaluators (35\% female and 65\% male; mean age of 22 years) who received the samples in monadic form, coded with three digits and randomised to avoid bias. The experimental design consisted of complete blocks, i.e., all evaluators analysed the samples using the scales presented here. The evaluators were asked to drink a glass of room-temperature water to rinse their mouth before each evaluation.

The sensorial acceptance of the samples was evaluated by analysing the following sensorial attributes: aroma, flavour, colour, and overall acceptance using a structured hedonic scale of nine points ( $9=$ I liked extremely and $1=$ I disliked extremely) (Reis \& Minim, 2010). Intention to buy, in turn, was evaluated using a structured five-point scale ( 1 = I certainly would not buy this sample and $5=$ I would certainly buy this sample) (Meilgaard et al., 2006).

The project was approved (Process number: 51957715.7.0000.5466) by the Committee of Ethics in Research Involving Humans of the Institute of Biosciences, Humanities and Exact Sciences of the São Paulo State University (IBILCE/UNESP).

\subsection{Data analysis}

The beers were produced with three replicates and the analyses were performed in triplicate. Physicochemical analyses of the beer samples and their sensorial attributes were compared using Analysis of Variance (ANOVA) followed by Tukey's multiple comparison test when $\mathrm{P}<0.05$. The results were further compared using an internal preference map, elaborated using cluster analysis followed by multidimensional scaling. All analyses were performed at 5\% level using Statistica 10.0 software (StatSoft Inc., USA).

\section{Results and discussion}

\subsection{Physicochemical characterisation}

Beers produced with different concentrations of artichoke showed similar original extract content $(\mathrm{P}>0.05)$ (Table 1). The small numerical difference observed among the original extract content of the samples could be explained by random changes of the process, such as grinding granulometry, or even mashing yield.

All original extracts of the beers were around $12^{\circ} \mathrm{P}$, agreeing with the values recommended by the Beer Judge Certification Program (BJCP) for American Lager beers, popularly known in Brazil as Pilsen (Strong \& England, 2015). The apparent extracts of the beers did not show significant differences among the samples evaluated. The lowest value observed was $3.3^{\circ} \mathrm{P}$ for standard beer, and the highest was $4^{\circ} \mathrm{P}$ for the sample containing $4 \mathrm{~g} \cdot \mathrm{L}^{-1}$ artichoke. Small changes in the apparent extract are related to changes inherent in the fermentation process, as observed by Piddocke et al. (2009) when evaluating the fermentative process of brewing worts with different sugar concentrations. The apparent attenuation did not differ statistically significantly among the evaluated conditions since all formulations obtained values around $70 \%$, which is usually the attenuation value obtained in the brewing process (Mayer et al., 2016; Rogers et al., 2016). Thus, the use of artichokes as a substitute for hops did not seem to hinder the fermentation process. Similarly, alcohol content, another variable correlated to the fermentation process, did not differ statistically significantly in the analysed samples. Strong \& England (2015) recommend that American lager beers should have an alcohol content between 4.2 and $5.3^{\circ} \mathrm{GL}$. Therefore, all the samples had an alcohol content as expected for Pilsen beers.

The colour and turbidity values of the samples containing artichoke differed significantly from the values of the commercial and standard samples. The commercial sample had a clearer colour and lower turbidity, which can be explained by the efficient methods of filtration the beer is subjected to (Cimini \& Moresi, 2018; Gassara et al., 2015). The other beers used in 
Table 1. Physicochemical characterisation of beers with different concentrations of artichoke.

\begin{tabular}{|c|c|c|c|c|c|c|c|}
\hline Samples & $\mathrm{OE}$ & $\mathrm{AE}$ & AA & $\mathrm{AC}$ & Colour & $\mathrm{T}$ & $\mathrm{B}$ \\
\hline Standard & $12.7^{\mathrm{a}}$ & $3.3^{\mathrm{a}}$ & $74.0^{\mathrm{a}}$ & $4.9^{\mathrm{a}}$ & $13.4^{\mathrm{a}}$ & $13.44^{\mathrm{a}}$ & 8.47 \\
\hline $1 \mathrm{gL}^{-1}$ artichoke & $12.3^{\mathrm{a}}$ & $3.5^{\mathrm{a}}$ & $71.5^{\mathrm{a}}$ & $4.7^{\mathrm{a}}$ & $23.7^{\mathrm{b}}$ & $25.13^{b}$ & \\
\hline \multirow[t]{2}{*}{$2 \mathrm{gL}^{-1}$ artichoke } & $12.3^{\mathrm{a}}$ & $3.6^{\mathrm{a}}$ & $70.7^{a}$ & $4.7^{\mathrm{a}}$ & $36.1^{c}$ & $36.54^{c}$ & \\
\hline & $(0.25)$ & $(0.35)$ & $(3.30)$ & $(0.31)$ & $(0.34)$ & $(0.05)$ & \\
\hline \multirow[t]{2}{*}{$4 \mathrm{gL}^{-1}$ artichoke } & $12.4^{\mathrm{a}}$ & $4.0^{\mathrm{a}}$ & $67.7^{\mathrm{a}}$ & $4.6^{\mathrm{a}}$ & $34.3^{c}$ & $33.63^{c}$ & \\
\hline & $(0.05)$ & $(0.3)$ & $(2.28)$ & $(0.13)$ & $(0.57)$ & $(0.53)$ & \\
\hline \multirow[t]{2}{*}{$5 \mathrm{gL}^{-1}$ artichoke } & $12.2^{\mathrm{a}}$ & $3.7^{\mathrm{a}}$ & $69.7^{\mathrm{a}}$ & $4.6^{\mathrm{a}}$ & $27.5^{b}$ & $28.81^{b}$ & \\
\hline & $(0.20)$ & $(0.10)$ & $(0.35)$ & $(0.07)$ & $(0.07)$ & $(0.08)$ & \\
\hline Commercial & & & & $4.5^{\mathrm{a}}$ & $6.4^{\mathrm{d}}$ & $1.16^{\mathrm{d}}$ & 7.03 \\
\hline
\end{tabular}

$\mathrm{OE}=$ original extract $\left({ }^{\circ} \mathrm{P}\right) ; \mathrm{AE}=$ apparent extract $\left({ }^{\circ} \mathrm{P}\right) ; \mathrm{AA}=$ apparent attenuation $(\%) ; \mathrm{AC}=$ alcohol content $\left({ }^{\circ} \mathrm{GL}\right) ; \mathrm{Colour}=$ colour $(\mathrm{EBC}) ; \mathrm{T}=$ turbidity $(\mathrm{EBC}) ; \mathrm{B}=$ bitterness $(\mathrm{IBU})$. Mean (standard deviation). The means followed by the different letters in the columns differ statistically significantly from each other by Tukey's multiple comparison test at $\mathrm{P}<0.05$.

the experiment showed greater turbidity because they did not undergo filtration. Chemical compounds like polyphenols and proteins, and yeast remnants from the fermentation process, promote high turbidity of beer when not subjected to the filtration process (Steiner et al., 2010). Another explanation for the greater turbidity found in the samples using artichoke as a substitute for hops is that, throughout the boiling process, the polyphenols of hops are complexed with proteins from the wort and other compounds, decanting and forming the trub, which is then removed (Jakubowski et al., 2016).

Bitterness intensity was determined only in standard and commercial samples, as this property is determined by the amount of hops alpha acids present in the beverage. Since the beers with artichoke did not have hops in their composition, it was not possible to detect bitterness intensity. It is noteworthy that the results obtained for the bitterness intensity of the standard and commercial beers range from 7 to 9 IBUs, values usually found in American Beers.

Thus, the data suggest that the use of bitter plants as a substitute for hops does not cause any negative changes to the physicochemical characteristics of the produced beers, which agrees with the results found by Okafor et al. (2016) and Adenuga et al. (2010), who also did not report changes in the physicochemical properties of beers made with different extracts of African plants.

\subsection{Sensory analysis}

The sensory evaluation of the samples containing artichoke in their formulation showed that the overall acceptance of the samples containing 1 and $2 \mathrm{~g} \cdot \mathrm{L}^{-1}$ artichoke did not differ from those obtained for the standard and commercial samples. It is noteworthy that all samples, even the standard and commercial, obtained 'I liked' (score 6) and 'I quite liked' (score 7) scores (Table 2).

An increase in artichoke concentration negatively influenced the overall acceptance of the beers. Thus, the sample with $5 \mathrm{~g} \cdot \mathrm{L}^{-1}$ artichoke was the least accepted, with a mean acceptance of 4.4. The acceptance of aroma followed a similar pattern to that of general acceptance, in which all samples with 1 and $2 \mathrm{~g} \cdot \mathrm{L}^{-1}$ artichoke had scores close to those of standard and commercial samples, whereas the sample containing $5 \mathrm{~g} \cdot \mathrm{L}^{-1}$ had the worst score. The degree of taste differed statistically significantly among the beers evaluated, following the same trend observed for aroma and overall acceptance, except for the sample containing $2 \mathrm{~g} \cdot \mathrm{L}^{-1}$ artichoke, which had lower acceptance than the standard, commercial and $1 \mathrm{~g} \cdot \mathrm{L}^{-1}$ artichoke samples.

Comparison of the colour attributes also resulted in significant differences, which suggests that using high artichoke concentrations (above $4 \mathrm{~g} \cdot \mathrm{L}^{-1}$ ) negatively influenced the colour acceptability of these samples. The results indicate that using artichoke in low concentrations is feasible and results in an acceptable colour, as the sample containing $1 \mathrm{~g} \cdot \mathrm{L}^{-1}$ artichoke had a significantly higher score than the commercial sample, which is a relevant result in the present study.

Grouping analysis of overall acceptance (Figure 1) and aroma (Figure 2) resulted in the formation of two sample groups following a similar pattern of acceptance. For both sensory attributes, a group consisting of the commercial samples, standard and $1 \mathrm{~g} \cdot \mathrm{L}^{-1}$ artichoke and another group formed by the 3,4 , and $5 \mathrm{~g} \cdot \mathrm{L}^{-1}$ artichoke samples were formed. The sample with $2 \mathrm{~g} \cdot \mathrm{L}^{-1}$ artichoke, located in the central region of the graph, did not considerably contribute to clustering analysis.

A higher concentration of evaluators found in the left area of the graph shows that the group containing the standard, commercial and lowest artichoke concentration $\left(1 \mathrm{~g} \cdot \mathrm{L}^{-1}\right)$ samples was the one with the higher overall acceptance and aroma acceptance among the samples evaluated, confirming the univariate analysis results.

The internal preference map shows that the lowest artichoke concentration samples had good acceptance by the evaluators, being in a position closely related to many evaluators and close to the standard beer. This result shows that the use of concentrations 
Table 2. Sensory acceptance of beers with different concentrations of artichoke.

\begin{tabular}{|c|c|c|c|c|c|}
\hline Sample & Colour & Aroma & Flavour & Overall acceptance & Intention to buy \\
\hline \multirow[t]{2}{*}{ Standard } & $7.26^{\mathrm{ab}}$ & $6.98^{a}$ & $6.54^{\mathrm{a}}$ & $6.58^{a}$ & $3.60^{\mathrm{a}}$ \\
\hline & $(1.22)$ & $(1.42)$ & $(1.87)$ & $(1.68)$ & $(1.17)$ \\
\hline \multirow[t]{2}{*}{1 g. $\mathrm{L}^{-1}$ Artichoke } & $7.63^{a}$ & $6.47^{\mathrm{a}}$ & $6.02^{a b}$ & $6.36^{\mathrm{a}}$ & $3.51^{\mathrm{ab}}$ \\
\hline & $(1.39)$ & $(1.65)$ & $(1.97)$ & $(1.89)$ & $(1.34)$ \\
\hline \multirow[t]{2}{*}{$2 \mathrm{~g} \cdot \mathrm{L}^{-1}$ Artichoke } & $6.99 \mathrm{abc}$ & $6.34^{\mathrm{abc}}$ & $5.53^{\mathrm{bc}}$ & $6.39^{\mathrm{a}}$ & $3.08^{b c}$ \\
\hline & $(1.51)$ & $(1.59)$ & $(2.18)$ & $(1.97)$ & $(1.38)$ \\
\hline \multirow[t]{2}{*}{$3 \mathrm{~g} \cdot \mathrm{L}^{-1}$ Artichoke } & $6.58^{b c}$ & $5.69 \mathrm{bc}$ & $4.81^{\mathrm{d}}$ & $5.88^{\mathrm{b}}$ & $2.58^{\mathrm{c}}$ \\
\hline & $(1.61)$ & $(1.92)$ & $(1.91)$ & $(2.16)$ & $(1.19)$ \\
\hline \multirow[t]{2}{*}{$4 \mathrm{~g} \cdot \mathrm{L}^{-1}$ Artichoke } & $5.61^{\mathrm{d}}$ & $5.75^{b c}$ & $4.52^{\mathrm{cd}}$ & $5.14^{\mathrm{bc}}$ & $2.59^{c}$ \\
\hline & $(1.97)$ & $(1.75)$ & $(2.22)$ & $(1.83)$ & $(1.06)$ \\
\hline \multirow[t]{2}{*}{$5 \mathrm{~g} \cdot \mathrm{L}^{-1}$ Artichoke } & $5.61^{\mathrm{d}}$ & $5.64^{\mathrm{c}}$ & $4.02^{\mathrm{d}}$ & $4.44^{c}$ & $2.18^{\mathrm{d}}$ \\
\hline & $(1.90)$ & $(1.79)$ & $(1.90)$ & $(2.01)$ & $(1.14)$ \\
\hline \multirow[t]{2}{*}{ Commercial } & $6.39^{c}$ & $6.39^{\mathrm{ab}}$ & $6.42^{\mathrm{a}}$ & $6.46^{\mathrm{a}}$ & $3.53^{\mathrm{ab}}$ \\
\hline & $(1.80)$ & $(1.90)$ & $(1.85)$ & (1.66) & (1.14) \\
\hline
\end{tabular}

Mean (standard deviation). The means followed by different letters in the columns differ statistically significantly from each other by Tukey's multiple comparison test at $\mathrm{P}<0.05$.
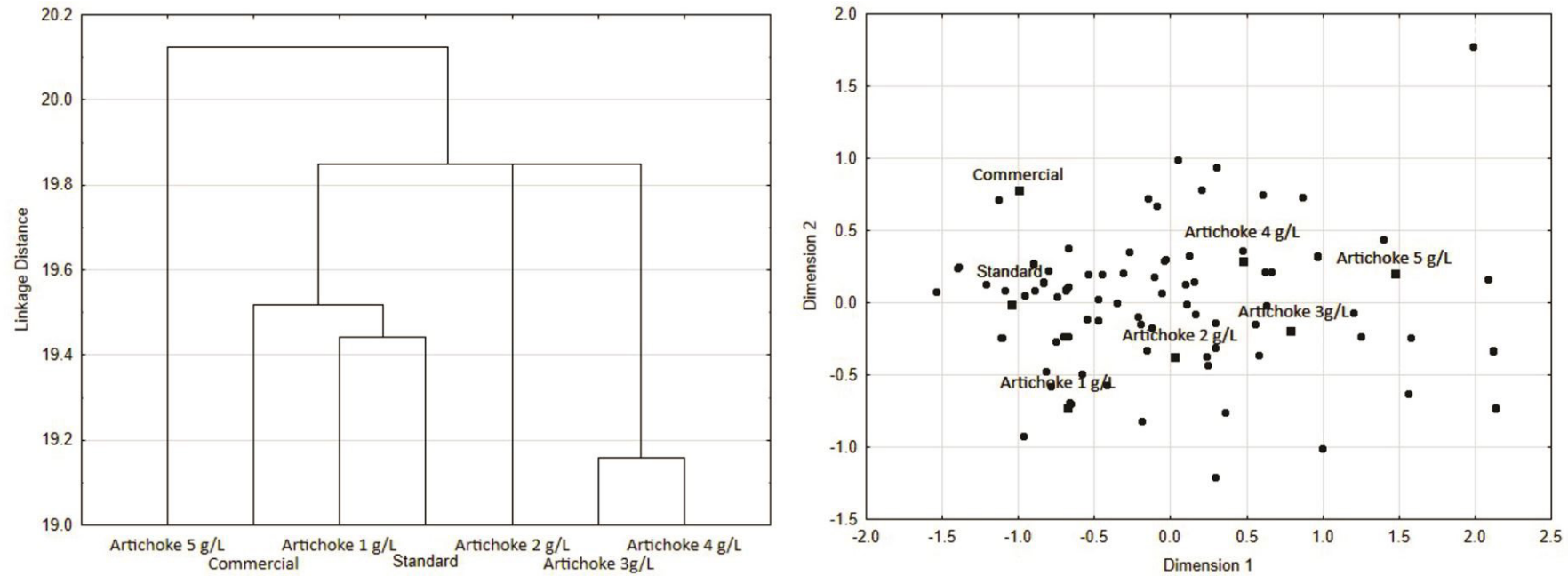

Figure 1. Dendrogram and internal preference map of overall acceptance of samples with different concentrations of artichoke.
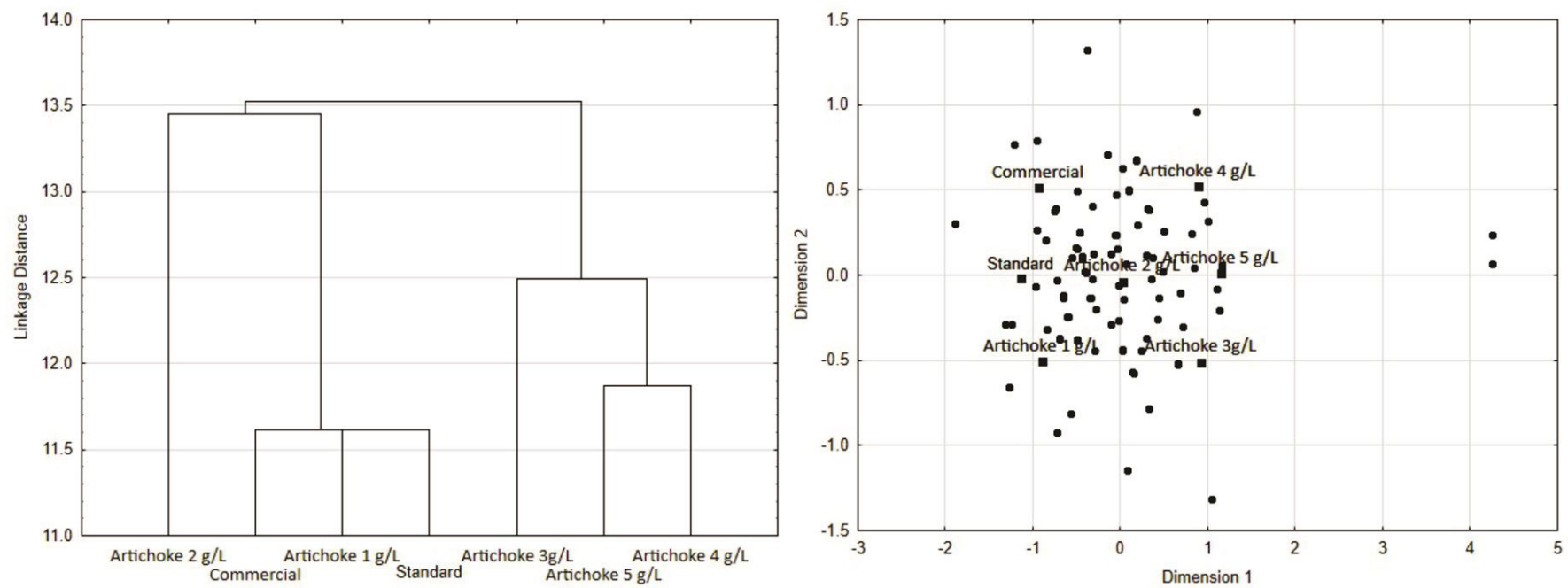

Figure 2. Dendrogram and internal preference map of the aroma of samples with different concentrations of artichoke. 
up to 2 g. $\mathrm{L}^{-1}$ of artichoke produces beers with proper sensory acceptation, having the potential to be used by the brewing industry. Otherside, higher the artichoke concentration in the beer composition, the lower its sensorial acceptance.

Intention to buy agreed with the other results, and, in this sense, beers with higher sensory acceptance had the highest scores of intention to buy.

\section{Conclusion}

We can assume from the results obtained in the present study that the use of artichoke as a substitute for hops in craft beer is feasible, as the beer samples had physicochemical properties similar to those of the Pilsen category and high sensorial acceptance in low concentrations of artichokes. The substitution of hops for up to $2 \mathrm{~g} \cdot \mathrm{L}^{-1}$ artichoke resulted in beers with similar quality to the American lager beer traditionally found in the Brazilian market. On the one hand, this relevant result confirmed the viability of using artichoke as a substitute for malt without significantly changing the chemical profile and sensory acceptance from those of commercial and standard samples, indicating the possibility for later production on a large scale.

\section{References}

Adenuga, W., Olaleye, O. N., \& Adepoju, P. A. (2010). Utilization of bitter vegetable leaves (Gongronema latifolium, Vernonia amygdalina) and Garcinia kola extracts as substitutes for hops in sorghum beer production. African Journal of Biotechnology, 9(51), 8819-8823.

Aniche, G. N., \& Uwakwe, G. U. (1990). Potential use of Garcinia kola as hop substitute in lager beer brewing. World Journal of Microbiology \& Biotechnology, 6(3), 323-327. http://dx.doi.org/10.1007/BF01201305. PMid:24430074.

Barry, S., Muggah, E. M., McSweeney, M. B., \& Walker, S. (2018). A preliminary investigation into differences in hops' aroma attributes. International Journal of Food Science \& Technology, 53(3), 804-811. http://dx.doi.org/10.1111/ijfs.13656.

Cimini, A., \& Moresi, M. (2018). Combined enzymatic and crossflow microfiltration process to assure the colloidal stability of beer. Lebensmittel-Wissenschaft + Technologie, 90, 132-137. http://dx.doi. org/10.1016/j.lwt.2017.12.008.

Costa, R. S., Ozela, E. F., Barbosa, W. L. R., Pereira, N. L., \& Silva-Júnior, J. O. C. (2009). Caracterização física, química e físico-química do extrato seco por nebulização (spray-drying) de Cynara scolymus L. (Asteraceae). Revista Brasileira de Farmácia, 90(3), 169-174.

Ernst, E. (1995). Die artischocke: eine heilpflanze mit geschichte und zukunftsperspektiven. Naturamed, 7, 1-4.

European Brewery Convention - EBC. (2010). Analytica-EBC. Nürnberg: Fachverlag Hans Carl.

Fintelmann, V. (1996). Antidyspeptische und lipidsenkende wirkungen von artischockenblätter-extrakt. Zeitschrift fur Allgemeinmedizin, 72, 48-57.

Gassara, F., Antzak, C., Ajila, C. M., Sarma, S. J., Brar, S. K., \& Verma, M. (2015). Chitin and chitosan as natural flocculants for beer clarification. Journal of Food Engineering, 166, 80-85. http://dx.doi. org/10.1016/j.jfoodeng.2015.05.028.

Jakubowski, M., Antonowicz, A., Janowicz, M., Sterczyńska, M., PiepiórkaStepuk, J., \& Poreda, A. (2016). An assessment of the potential of shadow sizing analysis and Particle Image Velocimetry (PIV) to characterise hot trub morphology. Journal of Food Engineering, 173, 34-41. http://dx.doi.org/10.1016/j.jfoodeng.2015.10.033.
Kraft, K. (1997). Artichoke leaf extract: recent findings reflecting effects on lipid metabolism, liver and gastrointestinal tracts. Phytomedicine, 4(4), 369-378. http://dx.doi.org/10.1016/S0944-7113(97)80049-9. PMid:23195590.

Leonardi, M., Skomra, U., Agacka, M., Stochmal, A., Ambryszewska, K. E., Oleszek, W., Flamini, G., \& Pistelli, L. (2013). Characterisation of four popular Polish hop cultivars. International Journal of Food Science \& Technology, 48(8), 1770-1774. http://dx.doi.org/10.1111/ ijfs. 12150 .

Mayer, H., Ceccaroni, D., Marconi, O., Sileoni, V., Perretti, G., \& Fantozzi, P. (2016). Development of an all rice malt beer: a gluten free alternative. Lebensmittel-Wissenschaft + Technologie, 67, 67-73. http://dx.doi.org/10.1016/j.lwt.2015.11.037.

Meilgaard, M. C., Carr, B. T., \& Carr, B. T. (2006). Sensory evaluation techniques (4th ed.). Florida: CRC Press. http://dx.doi.org/10.1201/ b16452.

Morado, R. (2009). Larousse da cerveja (1. ed.). São Paulo: Larousse.

Noldin, V. F., Cechinel, V. Fo., Monache, F. D., Benassi, J. C., Christmann, I. L., Pedrosa, R. C., \& Yunes, R. A. (2003). Composição química e atividades biolóicas das folhas de Cynara scolymus L. (alcachofra) cultivada no Brasil. Química Nova, 26(3), 331-334. http://dx.doi. org/10.1590/S0100-40422003000300008.

Okafor, V. N., Eboatu, A. N., Anyalebechi, R. I., \& Okafor, U. W. (2016). Comparative studies of the physicochemical properties of beers brewed with hop extracts and extracts from four selected tropical plants. Journal of Advanced Chemical Sciences, 2(4), 382-386. Retrieved from http://jacsdirectory.com/journal-of-advanced-chemical-sciences/ articleview.php?id=126

Piddocke, M. P., Kreisz, S., Heldt-Hansen, H. P., Nielsen, K. F., \& Olsson, L. (2009). Physiological characterization of brewer's yeast in high-gravity beer fermentations with glucose or maltose syrups as adjuncts. Applied Microbiology and Biotechnology, 84(3), 453-464. http://dx.doi.org/10.1007/s00253-009-1930-y. PMid:19343343.

Reis, R. C., \& Minim, V. P. R. (2010). Testes de aceitação. In V. P. R. Minim (Ed.), Análise sensorial: estudos com consumidores (2. ed., pp. 66-82). Viçosa: Editora UFV.

Rogers, C. M., Veatch, D., Covey, A., Staton, C., \& Bochman, M. L. (2016). Terminal acidic shock inhibits sour beer bottle conditioning by Saccharomyces cerevisiae. Food Microbiology, 57, 151-158. http:// dx.doi.org/10.1016/j.fm.2016.02.012. PMid:27052714.

Sanna, V., \& Pretti, L. (2015). Effect of wine barrel ageing or sapa addition on total polyphenol content and antioxidant activities of some Italian craft beers. International Journal of Food Science \& Technology, 50(3), 700-707. http://dx.doi.org/10.1111/ijfs.12666.

Schütz, K., Kammerer, D., Carle, R., \& Schieber, A. (2004). Identification and quantification of caffeoylquinic acids and flavonoids from artichoke (Cynara scolymus L.) heads, juice, and pomace by HPLCDAD-ESI/MS n. Journal of Agricultural and Food Chemistry, 52(13), 4090-4096. http://dx.doi.org/10.1021/jf049625x. PMid:15212452.

Silva, P. H. A., \& Faria, F. C. (2008). Avaliação da intensidade de amargor e do seu princípio ativo em cervejas de diferentes características e marcas comerciais. Food Science and Technology, 28(4), 902-906. http://dx.doi.org/10.1590/S0101-20612008000400021.

Sleiman, M., Venturini, W. G. Fo., Ducatti, C., \& Nojimoto, T. (2010). Determinação do percentual de malte e adjuntos em cervejas comerciais brasileiras através de análise isotópica. Ciência e Agrotecnologia, 34(1), 163-172. http://dx.doi.org/10.1590/S1413-70542010000100021.

Steiner, E., Becker, T., \& Gastl, M. (2010). Turbidity and haze formation in beer: insights and overview. Journal of the Institute of Brewing, 116(4), 360-368. http://dx.doi.org/10.1002/j.2050-0416.2010.tb00787.x.

Strong, G., \& England, K. (2015). Beer Judge Certification Program: 2015 style guidelines. St. Louis Park: BJCP. 